\title{
Flourishing Complexity of Conservatism and its Critique
}

Conservatism has, at least since the nineteenth century been one of the leading political ideologies of Modernity. Stasis believes it deserves more attention at the present moment, and the current issue shows how relevant conservative writing is in the contemporary context. The fact that conservatism, most of the time, nostalgically looks back does not signify that it is itself a phenomenon of the past. Just the opposite, it continues to be topical in everyday politics and is on the rise right now, in the often misrecognized shape of "populism." Against the tendency of many liberals to dismiss or demonize conservatism as a mere "reaction" driven exclusively by outrageous and outdated ideas, the authors of this issue, who differ in their ideological sympathies, share the will to take the conservatives seriously and study their arguments.

Some articles in this issue address contemporary conservative trends in political strategy as well as ideological production, such as Yannis Mylonas' analysis of the Greek "New Democracy” and John Feldmann's reconstruction of Jordan Peterson's intellectual system. Both point to a mixture of properly conservative elements with the more recent ones that usually look to us as liberal, or at least "progressive" : neoliberal entrepreneurialism, in the case of "New Democracy", and biological positivism/scientism in the case of Peterson. Here, Mylonas usefully relies on some pre-existing observations such as Corey Robin (2011) and Matthew McManus (2020): books that form an emerging corpus of conservatism studies in political theory.

Feldmann's exploration of Peterson's right-wing Darwinism rhymes with Anna Razuvalova's empirical study of the "Social-Darwinism” idiom in Russia's extreme Right rhetoric. Razuvalova shows how since the 1990s Russian conservative authors have detected and attacked the neoliberal strategies, which they frame through the pre-existing concept of Socio-Darwinism, and which were already widely used in Soviet anticapitalist writing (from the socialist perspective). Darwinism/Spencerism, a political, economic, and scientific doctrine of the mid-nineteenth century, is curiously today a key intersection of world visions. Darwinism is an ambivalent 
entity for the Right and a source of both seduction and fear for both the conservative neoliberals and the conservative anti-neoliberals.

Igor Kobylin's contribution, like Razuvalova's, refers to the 1990s in Russia and to the preceding late Soviet era, but this time the reference is not to the extreme right-wing dissident discourse but to the official, mainstream ideology of the time, where a leading role belonged to the "cybernetic." Kobylin studies the then-influential theories of the Soviet Academician Nikita Moiseyev as a symptomatic case. This has nothing to do with the aggressive conspiracy theories of Kara-Murza and Prilepin, but is an alliance between the new progressive technology, proto-neo-liberal utopia of governmentality, and the general values of world harmony and order. In the Russian context, like in Europe and the US, we thus find a divergence between establishment conservatism (standing for the orderly transactions that run top down from experts to the "backward populace") and the protest conservatism (determined through its ambivalent obsession with Darwinism and, more generally, with the competitive theories of society and life).

Andrey Teslya, an intellectual historian of the Russian nineteenth century, contributes with an important study of the powerful Russian nationalist Right of the time-the "Slavophiles." Teslya shows that, counterintuitively, Slavophiles were advocating a very mild version of conservatism that was closely intertwined with liberalism, a liberal conservatism of the kind that we encounter in today's Anglo-Saxon countries, or amongst the late Soviet intelligentsia like Nikita Moiseyev.

In the contemporary landscape, where the conservatives become increasingly neoliberal and neoliberals have always tended towards conservatism, it is important to remember of the existence of "true" conservatism: the direct defense of feudal privilege, contempt of the crowd, and celebration of war. Some of this we find in the Russian extreme Right described by Razuvalova, but there it is contaminated with the critique of the market. Georgy Vanunts, in his article, points at the strange case of unrepentant conservatism in the very midst of the liberal movement: the case of Joseph Schumpeter. Against the traditional view of Schumpeter as a fellow traveler of the neoliberal group, Vanunts shows him to be a figure apart: a conservative revolutionary with a post-feudal "entrepreneur" hero cult that is a wide departure from the rationalist, functionalist, and traditionalist discourse of Friedrich Hayek and Milton Friedman. Schumpeter emerges as a very contemporary figure that makes one think of the radical defenders of capitalism from the British "Cybernetic Culture Research Unit”. 
Sharing different political and philosophical perspectives, all of the authors nevertheless reject the simplistic view of conservatism as a false "ideology" that prevents its adherents from accepting authentic reality. On the contrary, conservatism-both as an intellectual tradition and as a trend of actual politics - is of interest precisely because it is an integral element of reality itself, its actual conflicts and contradictions. Such a thoughtful treatment of conservatism-as both an opposition to modernity and as a necessary part of it-can enrich our understanding of modernity as such.

Ilya Budraitskis, Artemy Magun 